hình thành của sự sắp xếp lại tổng thể NST.

Các đột biến di truyền ở BRCA1 và BRCA2, làm tăng nguy cơ phát triển ung thư vú hoặc ung thư buồng trứng suốt đời. Cả BRCA1 và BRCA2 đều tham gia vào việc duy trì sự ổn định của bộ gen, cụ thể là con đường tái tổ hợp tương đồng để sửa chữa DNA sợi đôi.

Gen BRCA1 và BRCA2 đôi khi được gọi là các gen ức chế khối u bởi khi các gen này biến thể theo hướng có hại thì tình trạng ung thư sẽ bắt đầu phát triển. Tại Mỹ, có khoảng $12 \%$ số phụ nữ sẽ bị ung thư vú vào một thời điểm nào đó trong đời. Tuy nhiên, nếu phụ nữ thừa hưởng gen BRCA1 biến thể có hại thì nguy cơ sẽ tăng lên $55-72 \%$ và sẽ tăng lên $45-69 \%$ nếu thừa hưởng biến thể có hại của gen BRCA2.

Cũng giống như những phụ nữ bị ung thư vú do các yếu tố khác, nhưng phụ nữ có biến thể có hại của gen BRCA1 và BRCA2 cũng sẽ tăng nguy cơ ung thư vú ở bên vú đối diên sau khi được chẩn đoán ung thư vú ở một bên. Nguy cơ ung thư vú ở bên đối diện sẽ tăng lên kể từ khi được chẩn đoán ung thư vú ở bên ban đầu, và sẽ đạt khoảng $20-30 \%$ sau 10 năm và khoảng $40-50 \%$ sau ít nhất 20 năm, phụ thuộc vào liều gen.

Phụ nữ mang biến thể có hại của gen BRCA1 và BRCA2 cũng sẽ bị tăng nguy cơ ung thư cổ tử cung. Nguy cơ sẽ tăng 39-44\% nếu mang biến thể có hại của gen BRCA1 và tăng $11-17 \%$ nếu mang biển thể có hại của gen BRCA2, trong khi đó, tỷ lệ mắc ung thư thông thường ở phụ nữ là $1,2 \%$ [8].

\section{KẾT LUÂ̂N}

Gen và các yếu tố về di truyền đóng một vai trò quan trọng trong việc biểu hiện kiểu hình về sức khỏe, vóc dáng, và nguy cơ mắc các bệnh chuyển hóa. Các nghiên cứu khoa học đã chứng minh, đột biến của một số gen có liên quan mât thiết đến một số vấn đề về các bệnh chuyển hóa, và sâu hơn nữa là có liên quan mật thiết đến dinh dương như khả năng dung nạp chất béo, nguy cơ thừa cân béo phì cũng như khả năng giảm cân... Việc triển khai và áp dụng xét nghiệm về gen trong đời sống (như xét nghiệm gen của CircleDNA) nhằm phát hiện ra mức độ nguy cơ của các gen bất thường có khả năng gây bệnh, hoặc tiềm năng di truyền có ý nghĩa trong định hướng phòng, điêu trị bệnh.

\section{TÀI LIÊU THAM KHẢO}

1. Tong, Y., et al., Association between TCF7L2 gene polymorphisms and susceptibility to type 2 diabetes mellitus: a large Human Genome Epidemiology (HuGE) review and meta-analysis. BMC Med Genet, 2009. 10: p. 15.

2. Gohlke, H., et al., SLC30A8 (ZnT8) Polymorphism is Associated with Young Age at Type 1 Diabetes Onset. Rev Diabet Stud, 2008. 5(1): p. 25-7.

3. Chang, W.C., et al., LDLR-mediated lipidometranscriptome reprogramming in cisplatin insensitivity. Endocr Relat Cancer, 2020. 27(2): p. 81-95.

4. Li $\mathbf{Z}$, et al., Polymorphisms in PCSK9, LDLR, BCMO1, SLC12A3, and KCNJ1 are Associated with Serum Lipid Profile in Chinese Han Population. Int J Environ Res Public Health., 2019. 16(17).

5. Hess, M.E. and J.C. Bruning, The fat mass and obesity-associated (FTO) gene: Obesity and beyond? Biochim Biophys Acta, 2014. 1842(10): p. 2039-47.

6. Baumert, $\mathbf{P}_{\text {., }}$ et al., Genetic variation and exercise-induced muscle damage: implications for athletic performance, injury and ageing. Eur J Appl Physiol, 2016. 116(9): p. 1595-625.

7. Boyajyan, A.S., S.A. Atshemyan, and R.V. Zakharyan, [Association of schizophrenia with variations in genes encoding transcription factors]. Mol Biol (Mosk), 2015. 49(6): p. 977-83.

8. Anastasiadi, Z., et al., Breast cancer in young women: an overview. Updates Surg, 2017. 69(3): p. 313-317.

\title{
KIẾN THỨC VỀ CHĂM SÓC NGƯờI BÊNH ĐÁI THÁO ĐƯờNG TÍP 2 CỦA NGƯỜI CHĂM SÓC CHÍNH TẠI HAI HUỴ̂̂̉N CỦA TỈNH THÁI BÌNH NĂM 2019
} Nguyễn Việt Khánh ${ }^{1}$, Lương Đức Sơn ${ }^{2}$, Nguyễn Đức Thanh ${ }^{1}$

TÓM TẮT.

Nghiên cứu mô tả kiến thức về chăm sóc người

${ }^{1}$ Trường Đại học Y Dược Thái Bình

'Sở Y tế Thái Binh

Chịu trách nhiệm chính: Nguyễn Đức Thanh

Email: bsthanh@hotmail.com

Ngày nhận bài: 18.10 .2021

Ngày phản biện khoa học: 20.12.2021

Ngày duyệt bài: 30.12.2021 bệnh đái tháo đường típ 2 của người chăm sóc chính cho người bênh. Đề tài áp dụng phương pháp nghiên cứu định lượng qua phỏng vấn 1.238 đối tượng là người chăm sóc chính cho người bênh đái tháo đường típ 2 tại hai huyện của tỉnh Thái Bình năm 2019. Kết quả: Người chăm sóc chiếm nhiều nhất là có trình độ học vấn tốt nghiệp trung học cơ sở $(38,8 \%)$, phần lớn là con $(53,8 \%)$, hoặc vớ/chồng $(39,0 \%)$ của người được chăm sóc. Trong số 7 nội dung chăm sóc được đánh giá, chế độ dinh dưỡng được đối tượng biết đển với điểm trung bình cao nhất $(2,74 \pm 0,85)$, tiếp đến là 
hướng dẫn người bệnh tập thể dục $(2,6 \pm 1,06)$. Các đối tượng thiếu hụt kiến thức chủ yếu về nội dung điều trị biến chứng của bệnh như: chăm sóc bàn chân, kiểm soát hạ đường huyết. Điểm trung bình của các

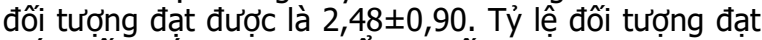
mức kiến thức cao (>2 điểm) chiếm 67,9\%. sóc.

Tư khóa: Đái tháo đường, kiến thức, người chăm

\section{SUMMARY}

KNOWLEDGE ON PATIENT CARE OF INFORMAL CAREGIVERS FOR PEOPLE WITH TYPE-2 DIABETES IN THAI BINH PROVINCE IN 2019

The study aimed to describe the current knowledge of informal caregivers on primary care of patients with type-2 diabetes. It applied the quantitative research method through interviews with 1,238 subjects who are key informal caregiver for people with type-2 diabetes in two districts of Thai Binh province in 2019. Results: informal caregivers for people with diabetes mainly completed secondary school $(38.8 \%)$, mostly children (53.8\%) or spouses $(39.0 \%)$ of caregivers. For 7 care contents, the highest average score abtained for nutrition (2.74 \pm 0.85$)$, followed by exercise instruction (2.6 \pm 1.06$)$. Subjects lacked knowledge mainly on treatment of disease complications such as foot care, hypoglycemia control. The mean score achieved was 2.48 \pm 0.90 . Percentage of subjects with high knowledge level ( $>2$ points) accounted for $67.9 \%$.

Keywords: Diabetes, knowledge, caregivers

\section{I. ĐĂT VẤN ĐỀ}

Đái tháo đường (ĐTĐ) có những tác động đáng kể đến tình trạng sức khỏe thể chất và tinh thần của người bệnh $[1,2]$. Việc hỗ trợ chăm sóc của những người không phải là nhân viên y tế cho người bệnh ĐTĐ típ 2 có tầm quan trọng đối với sức khỏe của người bệnh trong bối cảnh tỷ lệ mắc bệnh ĐTÐ trên thế giới đang gia tăng, và hầu hết ở các nước có thu nhập thấp và trung bình trong đó có Việt Nam $[3,4]$. Tại Việt Nam hiện có khoảng 5,76 triệu người mắc [5]. Hỗ trợ chăm sóc tại nhà cho người bệnh ĐTÐ thường là vợ hoặc chồng, con, hoặc anh chị em ruột hay những người thân khác của họ và đóng vai trò quan trọng trong việc cải thiện chất lượng cuộc sống của người bệnh $[6,7]$. Ngoài thông tin tiếp thu được từ hệ thống y tế, người chăm sóc tại nhà cũng là nguồn kiến thức quan trọng đối với người bệnh ĐTÐ $[8,9]$. Nghiên cứu này được thực hiện nhằm xác định thực trạng kiến thức về chăm sóc người bệnh đái tháo đường típ 2 của người chăm sóc chính để góp phần làm căn cứ cho việc hoạch định chính sách hỗ trợ nâng cao khả năng tiểp cận thông tin của họ.

II. Đốl TƯợNG VÀ PHƯƠNG PHÁP NGHIÊN CứU

2.1. Đối tượng nghiên cứu. Đối tượng nghiên cứu là người chăm sóc chính cho người bệnh ĐTÐ típ 2 đang điều trị ngoại trú tại Bệnh viện đa khoa của 2 huyện được lựa chọn. Người chăm sóc chính được xác định qua ý kiến của người bệnh; đây là những người có vai trò quan trọng nhất trong hỗ trợ chăm sóc, điều trị cho họ, có thể là vợ chồng, con, anh chị em.... của người được chăm sóc. Các đối tượng được lựa chọn phải là những người không mắc vấn đề về tâm thần; có mặt tại thời điểm điều tra; và tự nguyện tham gia nghiên cứu.

2.2. Địa điểm và thời gian nghiên cứu. Nghiên cứu được tiến hành tại 2 huyện Quỳnh Phụ và Vũ Thư, tỉnh Thái Bình, từ tháng 4/2019 đến hết tháng 9/2020.

2.3. Thiết kế nghiên cứu. Nghiên cứu mô tả cắt ngang đánh giá thực trạng kiến thức của người chăm sóc chính người bệnh ĐTÐ típ 2 thông qua phỏng vấn trực tiếp bằng bộ câu hỏi được xây dựng từ trước.

2.4. Cỡ mấu nghiên cứu. Cõ̃ mẫu được tính theo công thức:

$$
n=Z_{1-\alpha / 2}^{2} \times \frac{p(1-p)}{d^{2}} \times D E
$$

Trong đó: $\mathrm{n}$ : cõ mẫu tối thiểu cần nghiên cứu; $Z_{(1-\alpha / 2)}$ : Độ tin cậy lấy ở ngưỡng $95 \%\left[Z_{(1-}\right.$ $\alpha / 2)=1,96] ; \mathrm{p}$ : tỳ lệ người chăm sóc chính người bệnh ĐTÐ típ 2 tiếp cận đây đủ thông tin về chăm sóc người bệnh, vì chưa có số liệu nghiên cứu trước để tham chiếu, chọn $p=0,5$ để có cõ mẫu tối thiểu cần chọn lớn nhất; $\mathrm{d}$ : sai số tuyệt đối lựa chọn $(d=0,04)$; $D E$ : hiệu lực thiết kế (Design effect): vì áp dụng chọn mấu cụm, chọn $\mathrm{DE}=2$. Thay các giá trị trên vào công thức tính, cho kết quả số đối tượng cần thu thập là 1202 người chăm sóc chính. Thực tế đã điều tra toàn bộ 1.238 đối tượng.

\subsection{Phương pháp chọn mẫu}

- Chọn huyện, xã: Chọn chủ đích hai huyện là Quỳnh Phụ và Vũ Thư để làm địa bàn nghiên cứu. Tại mỗi huyện, chọn 1 thị trấn và 3 xã có số người mắc bệnh ĐTĐ cao nhất theo sổ quản lý của bệnh viện huyện. Đây là những người bệnh đang điều trị tại bệnh viện huyện tại thời điểm nghiên cứu. Kết quả có 8 xã và thị trấn của 2 huyện được chọn.

- Chọn người chăm sóc chính: Lập danh sách những người ĐTĐ sống trong 8 xã, thị trấn được lựa chọn thông qua danh sách quản lý người bệnh của bệnh viện huyện. Các nghiên cứu viên đã̃ gặp trực tiếp người bệnh để lập danh sách người chăm sóc chính của họ. 02 người chăm sóc chính được lựa chọn từ mỗi người bệnh ĐTÐ. Trường hợp người bệnh chỉ có một người 
chăm sóc thì người chăm sóc đó được chọn.

2.6. Phương pháp thu thập thông tin. Bộ công cụ phỏng vấn đối tượng được thiết kế, kiểm tra trước, được hiệu chỉnh bởi các chuyên gia chuyên ngành nội khoa, dược lâm sàng, y học gia đình và sức khỏe cộng đồng để đảm bảo tính dễ hiểu và phù hợp với văn hóa của các đối tượng.

Kiến thức của đối tượng được đánh giá bằng 07 câu hỏi: Ông/bà có đủ kiến thức về các nội dung sau đây khi chăm sóc người mắc bệnh ĐTĐ: 1) Chế độ ăn uống; 2) Cai thuốc lá; 3) Tập thể dục; 4) Tuân thủ dùng thuốc; 5 ) Chăm sóc bàn chân; 6) Kiểm soát lo âu; 7) Kiểm soát ha đường huyết. Các câu trả lời bao gồm: 1) Biết đủ; 2) Biết vừa phải; 3) Biết một ít; 4) Biết rất ít; và 5 ) Không biết.

Tổ chức tập huấn về mục đích phỏng vấn, thống nhất phương pháp thu thập thông tin. Điều tra viên phỏng vấn trực tiếp đối tượng tại nhà, nếu đối tượng đi vắng, sẽ gặp lại để tiếp tục phỏng vấn, nếu quay lại lần thứ 3 vẫn không gặp thì loại đối tượng khỏi cõ̃ mẫu điều tra.

2.7. Phương pháp xử lý số liệu. Tiến hành xử lý thô số liệu trước khi nhập liệu, nhập số liệu vào máy tính 2 lần và phân tích, xử lý số liệu theo chương trình SPSS 20.0. Các thông số thống kê, tính toán trong nghiên cứu: các thông số được thể hiên dưới dang số lương và tỷ lệ phần trăm, trình bày qua bảng và biểu đồ.

Tính điểm và xác định mức kiến thức như sau:

- Tính điểm kiến thức: Theo thang Likert 5 mức, cụ thể: Biết đầy đủ: 4 điểm; Biết vừa phải: 3 điểm; Biết một ít: 2 điểm; Biết rất ít: 1 điểm; Không biết: 0 điểm.

- Phân loại kiến thức: 'Biết đầy đủ' khi đạt 4 hoăc 3 điểm, 'Biết vừa phải" khi đạt 2 hoăc 1 điểm, 'Không biết' khi đạt 0 điểm. Nểu điểm kiến thức trung bình $\leq 2,0$, xác định là có 'Mức kiến thức thấp', >2,0, xác định là có 'Mức kiến thức cao'.

2.8. Đạo đức trong nghiên cứu. Nghiên cứu được Hội đồng đạo đức của trường Đại học Y Dược Thái Bình chấp nhận tại quyết định số 1209/HĐĐĐ năm 2018. Các đối tượng tự nguyên tham gia và có thể từ chối tham gia bất cứ lúc nào trong quá trình nghiên cứu. Phỏng vấn được thực hiện trong các phòng riêng do đối tượng khuyến nghị để giữ sự riêng tư của họ.

\section{KẾT QUẢ NGHIÊN CỨU}

3.1. Đặc điểm của đối tượng. Trong nghiên cứu của chúng tôi, tỷ lệ nam so với nữ trong số đối tượng gần tương đương nhau (48,8\% và $51,2 \%$ theo thứ tự). Độ tuổi trung bình của các đối tượng là 48,3 ( \pm 15.1$)$. Nghề nghiệp của đối tượng chủ yếu là nông dân $(25,1 \%)$, tiếp đến là công nhân $(18,8 \%)$. Số đối tượng nghỉ hưu chiếm tỷ lệ thấp hơn $(12,8 \%)$. Trong mối quan hệ với người bệnh được chăm sóc, phần lớn $(53,8 \%)$ đối tượng là con của người được chăm sóc, tiếp đến là vợ/chồng của người được chăm sóc $(39,0 \%)$.

Bảng 1. Trình độ học vấn của đôî tượng

\begin{tabular}{|c|c|c|}
\hline Trình độ học vấn & Số lượng & Tỷ lệ (\%) \\
\hline Chưa từng tới trường & 2 & 0,2 \\
\hline Tiểu học & 92 & 7,4 \\
\hline Trung học cơ sở & 481 & 38,8 \\
\hline Trung họ́c phổ thông & 338 & 27,3 \\
\hline Cao đằng, đại học & 307 & 24,8 \\
\hline Sau đại học & 18 & 1,5 \\
\hline Tổng & $\mathbf{1 2 3 8}$ & $\mathbf{1 0 0 , 0}$ \\
\hline
\end{tabular}

Theo kết quả thu được trong bảng trên, tỷ lệ đối tượng tốt nghiệp trung học cơ sở chiếm cao nhất $(38,8 \%)$, tiếp đến là trung học phổ thông (27,3\%). Số đối tượng có trình độ cao đẳng, đại học trở lên chiếm 24,8\%

\subsection{Kiến thức của người chăm sóc}

Bảng 2. Tỷ lệ đôi tượng tiếp cận thông tin qua nguồn thông tin đại chúng $(n=1238)$

\begin{tabular}{|c|c|c|}
\hline Nguôn thông tin & Số lượng & Tỷ lệ (\%) \\
\hline Tivi & 1018 & 82,2 \\
\hline Radio & 335 & 27,1 \\
\hline Báo, tạp chí & 309 & 25,0 \\
\hline Sách & 369 & 29,8 \\
\hline Internet & 776 & 62,7 \\
\hline Loa truyền thanh xã & 156 & 12,6 \\
\hline $\begin{array}{c}\text { Mạng xã hội } \\
\text { (facebook, zalo) }\end{array}$ & 766 & 61,9 \\
\hline Mạng xã hội khác & 403 & 32,6 \\
\hline Khác & 13 & 1,1 \\
\hline
\end{tabular}

Kết quả trong bảng trên cho thấy nguồn thông tin có tỷ lệ đối tượng tiếp cận cao nhất là tivi $(82,2 \%)$. Mang Internet và mañ xã hội đước đối tượng áp dụng để truy cập thông tin chiếm tỷ lệ lần lượt là $62,7 \%$ và $61,9 \%$.

Bảng 3. Tự nhận định kiến thức về chế độ ăn, tập thể dục và hướng dẫn bỏ hút thuốc

\begin{tabular}{|c|c|c|c|c|c|c|}
\hline \multirow{2}{*}{ Mức độ } & \multicolumn{2}{|c|}{ Chế độ ăn } & \multicolumn{2}{c|}{ Hướng dần tập thể dục } & \multicolumn{2}{c|}{ Hướng dần bỏ hút thuốc } \\
\cline { 2 - 7 } & $\mathbf{S L}$ & $\mathbf{\%}$ & $\mathbf{S L}$ & $\mathbf{\%}$ & $\mathbf{S L}$ & \% \\
\hline Biết đầy đủ & 848 & 68,5 & 772 & 62,3 & 795 & 64,3 \\
\hline Biết vư̌a phải & 369 & 29,8 & 381 & 30,8 & 362 & 29,2 \\
\hline
\end{tabular}




\begin{tabular}{|c|c|c|c|c|c|c|}
\hline Không biết & 21 & 1,7 & 85 & 6,9 & 81 & 6,5 \\
\hline Cộng & $\mathbf{1 2 3 8}$ & $\mathbf{1 0 0 , 0}$ & $\mathbf{1 2 3 8}$ & $\mathbf{1 0 0 , 0}$ & $\mathbf{1 2 3 8}$ & $\mathbf{1 0 0 , 0}$ \\
\hline
\end{tabular}

Bảng trên trình bày kết quả tự nhận định kiến thức của đối tượng về chế độ ăn uống cho người bệnh, theo đó, tỷ lệ đối tượng biết đầy đủ chiếm $68,5 \%$. Tỷ lệ có kiến thức đầy đủ về hướng dẫn tập thể dục lả $62,3 \%$. Kiến thức của đối tượng về hướng dẫn bỏ hút thuốc lá ở mức "biết đầy đủ" chiểm $64,3 \%$. Số đối tượng trả lời không biết chiếm tỷ lệ 6,5\%.

Bảng 4. Tự nhận định kiến thức về chăm sóc bàn chân, kiểm soát lo âu và đường huyết

\begin{tabular}{|c|c|c|c|c|c|c|}
\hline \multirow{2}{*}{ Mức độ } & \multicolumn{2}{|c|}{ Chăm sóc bàn chân } & \multicolumn{2}{c|}{ Kiếm soát lo âu } & \multicolumn{2}{c|}{ Kiếm soát đường huyết } \\
\cline { 2 - 7 } & $\mathbf{S L}$ & $\mathbf{\%}$ & $\mathbf{S L}$ & $\mathbf{\%}$ & $\mathbf{S L}$ & $\mathbf{\%}$ \\
\hline Biết đây đủ & 508 & 41,0 & 693 & 56,0 & 767 & 62,0 \\
\hline Biết vừa phải & 314 & 25,4 & 436 & 35,2 & 373 & 30,1 \\
\hline Không biết & 416 & 33,6 & 109 & 8,8 & 98 & 7,9 \\
\hline Cộng & $\mathbf{1 2 3 8}$ & $\mathbf{1 0 0 , 0}$ & $\mathbf{1 2 3 8}$ & $\mathbf{1 0 0 , 0}$ & $\mathbf{1 2 3 8}$ & $\mathbf{1 0 0 , 0}$ \\
\hline
\end{tabular}

Theo bảng trên, kiến thức tự nhân định của đối tượng về hướng dẫn chăm sóc bàn chân ở mức "biết đầy đủ" chiếm 41,0\%. Số không biết chiếm tỷ lệ khá cao, ở mức $33,6 \%$. Kiến thức về kiểm soát lo âu cho người bênh ở mức "biết đây đủ" chiếm $56,0 \%$. Số đối tượng trả lời không biết chiếm tỷ lệ $8,8 \%$. Tỷ lệ có kiến thức về kiểm soát đường huyêtt ở mức 'biết đầy đủ' chiếm $62 \%$, số đối tượng trả lời 'không biết' chiếm 7,9\%.

Bảng 5. Điểm kiến thức trung bình của đôi tượng về 7 nội dung hỗ trợ

\begin{tabular}{|c|c|c|}
\hline Nối dung & Mean & I SD \\
\hline \multicolumn{2}{|c|}{ Điếm trung bình từng nội dung } \\
\hline Dinh dưỡng & 2,74 & $\pm 0,85$ \\
\hline Bỏ hút thuốc & 2,59 & $\pm 1,05$ \\
\hline Tập thế dục & 2,60 & $\pm 1,06$ \\
\hline Sự dụng thuốc & 2,71 & $\pm 1,15$ \\
\hline Chăm sóc bàn chân & 1,76 & $\pm 1,45$ \\
\hline Kiếm soát lo âu & 2,40 & $\pm 1,07$ \\
\hline Kiếm soát hạ đường huyết & 2,57 & $\pm 1,13$ \\
\hline Điếm trung bình chung & 2,48 & $\pm 0,90$ \\
\hline
\end{tabular}

Kết quả bảng trên cho thấy, trong số 7 nội dung chăm sóc được đánh giá, chế độ dinh dưỡng được đối tượng biết đến với điểm trung bình cao nhất $(2,74 \pm 0,85)$, tiếp đến là hướng dẫn người bệnh tập thể dục $(2,6 \pm 1,06)$. Điểm trung bình chung cho các nội dung là 2,48 $\pm 0,90$.

Bảng 6. Mức kiến thức đạt được của đôi tương

\begin{tabular}{|c|c|c|}
\hline Mức kiến thức & Số lượng & Tỷ lệ (\%) \\
\hline $\begin{array}{c}\text { Đạt mức kiến thức thấp } \\
\text { ( } 2 \text { 2 điểm) }\end{array}$ & 840 & 32,1 \\
\hline $\begin{array}{c}\text { Đạt mức kiến thức cao } \\
\text { (>2 điểm) }\end{array}$ & 398 & 67,9 \\
\hline Cộng & $\mathbf{1 2 3 8}$ & $\mathbf{1 0 0 , 0}$ \\
\hline
\end{tabular}

Kết quả bảng trên cho thấy, tỷ lệ đối tượng đạt mức kiến thức cao chiếm $67,9 \%$. Số còn lại đạt mức kiến thức thấp.

\section{BÀN LUÂN}

Nghiên cứu của chúng tôi cho thấy kiến thức chung của người chăm sóc chính cho người bênh ĐTÐ hiện còn ở mức thấp. Điểm kiến thức trung bình tính theo thang điểm 4 điểm đối với 7 nồi dung chăm sóc thì chế độ dinh dưỡng được đổi tương biết đến với điểm cao nhất $(2,74 \pm 0,85)$, tiếp đến là hướng dẫn người bệnh tập thể dục $(2,6 \pm 1,06)$. Điểm trung bình chung cho toàn bộ 7 nội dung được khảo sát là $2,48 \pm 0,90$. Đây cũng là điều đáng khích lệ khi điểm trung bình của các nội dung khảo sát ở mức trên trung bình. Mặc dầu vậy việc chăm sóc người bệnh nói chung, người bệnh ĐTÐ típ 2 nói riêng yêu cầu người chăm sóc phải có kiến thức ở mức tốt hơn nữa. Có thể thấy kiến thức của những người chăm sóc đặc biệt thấp với nội dung chăm sóc các biến chứng của bênh. Thực tế cho thấy chăm sóc biến chứng của bênh ĐịĐ như biến chứng bàn chân đòi hỏi sự chăm sóc một cách kiên trì, chu đáo và hệ thống của người chăm sóc cũng như sự hợp tác của người bệnh. Kết quả trên của chúng tôi cũng phù hợp với kết quả trong một nghiên cứu của Masami $M$ và cộng sự, theo đó, phần lớn những người chăm sóc đã báo cáo là kiến thức của họ còn thiếu và yếu; tỷ lệ người chăm sóc có mức độ hiểu biết thấp về các hoạt động chăm sóc khá cao, theo đó hai phần ba (254/376, 67,6\%) đối tượng là người dân trưởng thành đã cho biết ho hoặc không hiểu hoặc chưa bao giờ nghe nói về bệnh ĐTĐ [10]. Điều này cho thấy sự cần thiết phải tăng cường hỗ trợ người chăm sóc cho người bệnh ĐTÐ trong thời gian tới để ho có kiến thức tốt hơn, tự tin hơn trong công việc hỗ trợ, chăm sóc người bệnh.

\section{KẾT LUẦN}

Từ kết quả nghiên cứu trên 1238 người chăm sóc chính của người bênh ĐTÐ típ 2 tại hai huyên của tỉnh Thái Bình chúng tôi có kết luân sau: Người chăm sóc chính cho người bệnh ĐTÐ chủ yêuu tốt nghiệp THCS, phần lớn là con hoặc vợ/chồng của người được chăm sóc. Các đối 
tượng thiếu hut kiến thức chủ yếu về nội dung điều trị biến chứng của bệnh như: chăm sóc bàn chân, kiểm soát hạ đường huyết. Điểm trung bình (thang điểm 4) của các đối tượng đạt được là $2,48 \pm 0,90$. Tỷ lê đối tượng đạt mức kiến thức cao ( $>2$ điểm) chiếm $67,9 \%$.

Lời cảm ơn: Nghiên cứu này được Bộ Ngoại giao Đan Mạch tài trơ qua dự án "Sống chung với bênh man tính: Hổ trơ khồng chính thức cho quản lý bệnh đái tháo đường ở Việt Nam" (số 17-M09-KÜ). Chúng tôi rất cảm ơn các cơ quan y tế tuyến tỉnh, huyện, xã tại Thái Bình đã giúp đõ chúng tôi thu thập thông tin cho cuộc khảo sát.

\section{TÀI LIÊU THAM KHẢO}

1. World Health Organization (WHO). Global Report on Diabetes 2016. https:// apps.who.int/iris/handle/10665/204871

2. McInnes, AD. Diabetic foot disease in the United Kingdom: about time to put feet first. J Foot Ankle Res 5, 26 (2012). https://doi.org/10.1186/17571146-5-26

3. Whiting DR, Guariguata $L$, Weil $C$, et al. IDF diabetes atlas: global estimates of the prevalence of diabetes for 2011 and 2030. Diabetes Res Clin Pract. 2011 Dec; 94(3):311-21.

4. International Diabetes Federation (IDF). IDF
Diabetes Atlas, http://fmdiabetes.org/wpcontent/uploads/2018/03/IDF-2017.pdf

5. Nguyen BN, Zhou LL and Waqas AD. Diabetes: What Challenges Lie Ahead for Vietnam? Ann Glob Health. 2020; 86(1): 1. Published online 2020 Jan 2. doi: $10.5334 /$ aogh. 2526

6. Rosland AM, Piette JD, Choi $\mathrm{H}$, et al. Family and friend participation in primary care visits of patients with diabetes or heart failure: patient and physician determinants and experiences. Med. Care. 2011; 49: 37-45.

7. Messenger G, Taha N, Sabau S, et al. Is there a role for informal caregivers in the management of diabetic foot ulcers? A narrative review. Diabetes Ther. 2019; 10(6): 2025-2033.

8. Duggan A. Understanding interpersonal communication processes across health contexts: advances in the last decade and challenges for the next decade. J. Health Commun. 2006; 11 (1): 93-108.

9. Matthews AK, Sellergren SA, Manfredi C, et al. Factors influencing medical information seeking among African American cancer patients. J. Health Commun. 2002; 7 (3): 205-219.

10. Masami M, Takayuki S, Nguyen VD, et al. (2017), "Prevalence, perception and factors associated with diabetes mellitus among the adult population in central Vietnam: a population-based, cross-sectional seroepidemiological survey". BMC Public Health 17:298.

\title{
KHẢO SÁT ĐĂC ĐIỂM LÂM SÀNG KHẢ NĂNG PHỤC HỒI NGÔN NGŨ̃ CỦA TRẺ ĐIỂC BẨM SINH SAU PHẪU THUÂTT CẤY ỐC TAI ĐIỆN TỬ
}

\author{
Nguyễn Thanh Vũ*, Phạm Thị Minh Anh*, Đặng Thị Dượt*,
} Nguyễn Ngọc Thành Đạt*, Huỳnh Hoàng Minh*, Chiêm Hoàng Nhân*.

\section{TÓM TẮT}

Mục tiêu: Khảo sát các đặc điểm lâm sàng và sự phuc hồi thính giác của trẻ sau phấu thuât cây ốc tai điên tử. Thiết kế nghiên cứu: Hồi cứu và tiến cứu mồ tả loạt ca. Phương pháp: Khảo sát các đặc điểm lâm sàng và khả năng phục hồi thính giác của trẻ qua đánh giá lâm sàng trên thang điểm CAP. Kết quả: Chúng tôi nghiên cứu 39 trẻ điếc bẩm sinh đã phẫu thuât cấy ốc tai điện tữ tai Bênh viên Tai - Mũi - Họng TPHCM từ 01/2018 đến 04/2020 gồm 20 trẻ nam và 19 trẻ nữ. Đố tuổi phâ̂u thuật từ 1 đến 13 tuổi (trung bình $3.92 \pm 2.87$ tuổi), trong đó đa số trẻ cấy ốc tai điên tử tữ 1 đến 3 tuối $(61.54 \%)$. Số trẻ được cấy môt tai là $23 / 39$ trẻ $(58,97 \%)$. Số trẻ được cấy hai tai là $16 / 39$ trẻ $(41,03 \%)$. Sau phẫu thuật 1 năm, tất cả trẻ đat CAP từ 5 điểm trở lên, trong đó $87.18 \%$ trẻ đat CÁP từ 6 đến 7 điểm. CAP trung bình sau 1 năm cẩy

*Đại học Quốc Gia - Tp. Hồ Chí Minh

Chiu trách nhiệm chính: Nguyễn Thanh Vũ

Email: bsntvu@gmail.com

Ngày nhận bài: 18.10.2021

Ngày phản biện khoa học: 20.12 .2021

Ngày duyệt bài: 29.12.2021 ốc tai điện tử là $6.18 \pm 0.64$. Kết Iuận: Chúng tôi nghiên cứu 39 trẻ điếc bẩm sinh gồm 20 trẻ nam và 19 trẻ nữ. Độ tuổi phẫu thuật từ 1 đến 13 tuổi). Số trẻ được cây một tai là $23 / 39$ trẻ $(58,97 \%)$. Điểm CAP của tất cả trẻ có xu hướng tăng mạnh và về gần bình thường trong vòng 1 năm sau phấu thuật. Cấy ốc tai điện tử 2 bên cho hiệu quả phục hồi thính giác cao hơn.

Tư khóa: nghe kém, điếc bẩm sinh, ốc tai điện tử, phục hồi thính giác.

\section{SUMMARY}

\section{DETERMINE THE CLINICAL FEATURES AND EFFECTS OF AUDITORY REHABILITATION IN CHILDREN AFTER OF COCHLEAR IMPLANTATION}

Purpose: This study aimed to determine the clinical features and effects of auditory rehabilitation in children after of cochlear implantation. Study design: Retrospective and prospective descriptive study. Method: Determine the clinical features and effect $s$ of auditory rehabilitation in children according to the CAP scale. Result: Thirty nine children with congenital deafness (20 boys and 19 girls) who received cochlear implants at the Ho Chi Minh City Otorhinolaryngology Hospital (January 2018-April 2020) were included in this study. Age at CI ranged from 1 to 13 years (mean 